\title{
Engineering the Structure of Multi-thread Fancy Bouclé Yarn: Individual Effects of the Number of Wraps and the Overfeed Ratio
}

\author{
Malek Alshukur $^{1,2}$ (D) Lisa Macintyre ${ }^{1}$
}

Received: 16 January 2021/Accepted: 11 August 2021/Published online: 13 September 2021

(C) The Author(s) 2021

\begin{abstract}
This study is about the influence of the number of wraps and the overfeed ratio on the fancy boucle yarn structure. The bouclé yarns of this study were made on a hollow-spindle spinning system. The number of wraps and the overfeed ratio were increased incrementally and individually in two different experiments. It was found that there were significant linear relationships between increasing the overfeed ratio and increasing the number and size of fancy bouclé profiles, but at the expense of decreasing their circularity ratio and changing the bouclé yarn morphology. However, increasing the number of wraps made a significant linear reduction to the size of fancy bouclé profile but without affecting their number. This study aids bouclé yarn manufacturers to increase their understanding of the structure and aesthetics of bouclé yarns. It also shows them how the morphology of bouclé profiles may change when the overfeed ratio or the number of wraps is changed. In particular, variants of bouclé profiles may appear, which can increase the potential for those variants to attract the attention of designers and consumers. It also can strengthen the manufacturers' capabilities to satisfy the needs of a wide range of consumers, by creating a wider range of novelty clothing.
\end{abstract}

Malek Alshukur

malekshukur@yahoo.com

1 School of Textiles and Design, Heriot-Watt University, Netherdale Road, Galashiels TD1 3HF, UK

2 Department of Mechanical Engineering of Textiles Industries and Their Technologies, Faculty of Mechanical and Electrical Engineering, Damascus University, Damascus, Syria
Keywords Fancy bouclé yarn - Yarn structure . Overfeed ratio - Number of wraps .

Circularity ratio of fancy profile · Yarn morphology

\section{Introduction}

Fancy yarns can be made on hollow-spindle spinning systems using ordinary yarns as input materials. Those input materials are combined together to make the final overfed-fancy yarns that have multiple-thread structures. The input effect component is overfed in comparison with the core component, and the ratio of the effect length to the core component length is called the overfeed ratio. This ratio can also be calculated using the speeds of movement of these two components while making the final fancy yarn. This ratio is typically more than $110 \%$. Those two components are fastened together using a third component called the binder or wrapper component. The binder for most types of fancy yarns wraps around both the core and effect components helically many times per unit length, and these are called the number of wraps. One of the basic types of fancy yarn is bouclé yarn, which is defined as "A compound yarn comprising a twisted core with an effect yarn combined with it so as to produce wavy projections on its surface.... Generally speaking, bouclé yarns exhibit an irregular pattern of semi-circular loops and sigmoid spirals" [1]. The effect profiles on the surface of bouclé yarns are irregular, semi-circular loops in bouclé yarns [1].

Several studies were conducted to show the effect of the overfeed ratio on the structure of multi-thread fancy yarn, in particular those that are typically made on the hollowspindle system [2-6]. Those studies showed that although increasing the overfeed ratio may increase the total number of fancy profiles, it may also affect the dimension [2] or, 
most importantly, type of the resultant fancy profiles [4]. Consequently, it may increase the number of one particular type of fancy profile [5] at the expense of a reduction in the number of another type of profile [6]. In one particular study, it was found that the number of all effect profiles, including loops and knots, increased significantly with increasing the overfeed ratio [3]. Further, a proportional relationship was found between the overfeed ratio and the number of plain knot-knot profiles made of various loops [5]. However, it was shown that the increase in the overfeed ratio made a reduction to the number of opened looparc profiles [6]. In another study, it was found that regardless of direction of wraps or the number of wraps, the height of the bouclé profiles became significantly high when the overfeed ratio was increased from $100 \%$ to $200 \%$ [2]. Further experimental work showed that by increasing the overfeed ratio the height and the width of the resultant effect profiles and the number of those profiles increased, whilst the distance between those profiles decreased. In summary, the overfeed ratio was found to have an impact on the type of the resulting fancy profiles [4]. Repeating the same experimental work, but using different materials showed that increasing the overfeed ratio has changed the type of the resultant fancy profiles which were spirals, arcs, open and closed loops [7]. In a more recent study, it was found that increasing the overfeed ratio, at fixed and low value of the delivery speed, has led to similar increases in the number of loop/knot and plain knot effect profiles. However, further increases to the overfeed ratio did not increase the number of those profiles due to changes in the type of the resultant fancy profiles [8]. Such a change was explained by the changes in the length of the effect thread available to create the fancy profiles on the intermediate product within the hollow spindle. Therefore, such a study showed that there were maximum limits to the overfeed ratio where exceeding it does not help in improving the fancy yarn structure; instead, it may change the type of fancy profiles. These changes to the nature of the intermediate product within the hollow-spindle were discussed in two recent studies $[9,10]$. These two studies showed that the changes to the intermediate product originate from the changes that happen to the effect thread helices in the first spinning zone of hollow-spindle machine. This zone is located between the first drafting roller and the input hole of the hollow-spindle.

To account for the importance of wraps to the structure and geometry of fancy yarns made on hollow-spindle machines, several researchers studied combinations of the delivery speed and the rotational speed [3-8]. Those studies were conducted at more than one level of the supply speed such that there would usually be three values for the overfeed ratio. To be able to do so, those researchers based their work on the design of experiment method using a
Box-Behnken experimental design or composite experimental design which are basic response surface methodology designs. Other studies were also reported on bouclé yarns, variants of bouclé yarn, gimp yarns and fancy overfed yarns. These studies were concerned with structure and aesthetic profiles [11, 12]. A simpler approach, but without using the design of experiment technique, was followed in other studies [2, 13]. Generally speaking, the results of those studies were similar in the sense that increasing the number of wraps led to increases in the total number of profiles and reducing their dimensions or changing the type of the fancy profiles. However, it was found that when the input materials were changed, the effect of the number of wraps disappeared [3, 4, 7]. Although the researchers did not present an explanation for these findings, it may be explained by either changes in the bending stiffness of the input yarns as demonstrated recently $[14,15]$, or changes to the level of tension endured by the core thread while making the final fancy yarns, which was shown to have a significant effect [16]. In another study, it was reported that the number of opened loop-arc profiles increased when the number of the wraps was increased [6]. This result was attributed to the changes in the length of the effect component required to make the fancy effects. It was thought that when the number of wraps decreases, the pressure of the binder on the intermediate product, within the hollow-spindle, may decrease. Consequently, it may result in slacker wrappings, while the unwrapped lengths of the intermediate product increase. In a more recent study, it was reported that increasing the number of wraps, at fixed and low values of delivery speed, led to a similar increase in the number of loop/knot and plain knot effect profiles. However, overwrapping the resultant fancy yarns made a reduction to the number of those fancy profiles, even when the overfeed ratio was increased [8]. The researchers thought that the reason for this result was the changes in the length of the effect thread available for each fancy profile while being made. The previous changes to the structure of multi-thread fancy yarn were experimentally approached, but recently, a mathematical model of the structure of multi-thread fancy yarn showed the effect of the number of wraps and the overfeed ratio analytically [17]. Such a model showed the way in which changing the number of wraps and the overfeed ratio may change the number and type of fancy profiles. Eventually, the researchers were able to define the type of the final fancy yarn based on the properties of the structure model.

To date, the studies conducted specifically on fancy bouclé yarn are limited. Although it is possible to guess that increasing the overfeed ratio would increase the number and/or size of the resultant boucle profiles, it had not been reported whether it would change the morphology 
or the shape of boucle profiles into another fancy profile type. It is true that minor changes in the fancy profile morphology would not change fancy yarn type, but if their shape changed substantially, a different fancy yarn would be formed. In financial terms, changing the morphology of bouclé profiles would improve their style, and thus gain financial benefits. However, changing the shape of bouclé profiles into a different shape may lead to financial loss due to reductions in their appeal and thus price. Similarly, it was also unkown changing the number of wraps would change the morphology of the final fancy bouclé profiles. Based on that, this study was conducted to answer these questions by reporting the individual effects of the overfeed ratio and the number of wraps on the structure of multi-thread fancy bouclé yarns that are made on hollowspindle spinning machines.

\section{Methodology}

The bouclé yarns were made on a hollow-spindle spinning system Gemmill and Dunsmore \#3. For testing the influence of the overfeed ratio on the structure of bouclé yarn, the materials are given in Table 1 . The bending stiffness of the input threads was measured using a specially made bending frame [18]. The use of two threads (whether singles or ply) to create the effect component of the boucle yarns in this study helped to obtain fancy projections which resulted in the majority of them are either boucle profiles or semi-bouclé profiles, while the use of only one effect thread (whether single or ply) was incapable of delivering bouclé profiles or semi-bouclé profiles and the final fancy yarn would be a general overfed fancy yarn that would have a variety of fancy profile types. The term "semibouclé profile" may include U-shaped profiles; elongated loop profiles, which may be semi-circular, closed profiles; and open-based, flexed bouclé profiles. The settings of the machine for the overfeed ratio experiment are given in Table 1 . The theoretical number of wraps $\left(\mathrm{W}_{\text {theoretical }}\right)$ for this experiment is given by the following equation:

$W_{\text {theoretical }}=\mathrm{RS} / \mathrm{DS}$

where $W_{\text {theoretical }}$ is the theoretical number of wraps of the binder $\left(\mathrm{m}^{-1}\right)$, RS is the rotational speed of the hollowspindle $\left(\mathrm{min}^{-1}\right)$, and DS is delivery speed of the ultimate fancy yarn $\left(\mathrm{m} \mathrm{min}^{-1}\right)$.

For testing the influence of number of wraps on the structure of boucle yarn, the materials used are given in Table 2. The settings of the machine and the structural parameters of the resultant bouclé yarns are given in Table 3. The nominal, theoretical overfeed ratio $(\eta \%)$ for this experiment is given by the following equation:

$\eta=\left(\frac{\mathrm{SS}}{\mathrm{DS}}\right) \times 100$

where SS is the supply speed of effect component(s) (m $\left.\min ^{-1}\right)$, So, $\eta=(60 / 30) \times 100=200 \%$.

The bouclé yarns were assessed quantitatively and objectively using the quality parameters of fancy yarns $[19,20]$ which include the number of fancy profiles $(N)$, the size of fancy profile or area of fancy profile $(A)$, the circularity ratio of fancy profile (CR), the shape factor of fancy yarn (ShF) and the linear density of fancy yarn. These quality characteristics were also used in other studies $[9,10,16,21]$. To apply the objective method, a microscope having a magnifying power of 4 times was used. For the fancy profiles tested, a suitable transparent plate made from glass was used to fix the fancy profile underneath it to flatten the fancy profile into a plane if it was not already so. Following this, a digital photograph was taken for each fancy profile fixed by the transparent plate. The number of the digital images was the same as the number of samples

Table 1 Materials used for making the bouclé yarns

\begin{tabular}{|c|c|c|c|c|c|}
\hline Experiment & Component & Material type & $\begin{array}{l}\text { Number of } \\
\text { threads }\end{array}$ & $\begin{array}{l}\text { Resultant linear } \\
\text { density, tex }\end{array}$ & $\begin{array}{l}\text { Bending stiffness }( \pm \mathrm{SD}) \\
\left(\mathrm{g} \mathrm{mm}^{2}\right)\end{array}$ \\
\hline \multirow{3}{*}{$\begin{array}{l}\text { The overfeed ratio } \\
\text { experiment }\end{array}$} & Effect & Two-ply pure wool thread & 2 & $120 / 2$ & $4.006( \pm 1.116)$ \\
\hline & Core & $\begin{array}{l}\text { Two-ply blended } \\
\text { lambswool/cotton thread }\end{array}$ & 1 & $120 / 2$ & $3.662( \pm 1.774)$ \\
\hline & Binder & $\begin{array}{l}\text { Multifilament PA } 6.6 \text { yarn (77 } \\
\text { filament) }\end{array}$ & 1 & 14.5 & Not applicable \\
\hline \multirow[t]{3}{*}{$\begin{array}{l}\text { The number of wraps } \\
\text { experiment }\end{array}$} & Effect & $\begin{array}{l}\text { Two-ply blended wool/ } \\
\text { polyamide thread }\end{array}$ & 2 & $120 / 2$ & $3.183( \pm 1.671)$ \\
\hline & Core & $\begin{array}{l}\text { Two-ply blended } \\
\text { lambswool/cotton thread }\end{array}$ & 1 & $120 / 2$ & $3.662( \pm 1.774)$ \\
\hline & Binder & $\begin{array}{l}\text { Multifilament PA } 6.6 \text { yarn (77 } \\
\text { filament) }\end{array}$ & 1 & 14.5 & Not applicable \\
\hline
\end{tabular}


Table 2 Machine settings and yarn structure when testing the effect of the overfeed ratio

\begin{tabular}{|c|c|c|c|c|c|c|}
\hline $\begin{array}{l}\text { Machine } \\
\text { setting }\end{array}$ & $\begin{array}{l}\text { Delivery speed (DS) } \\
\left(\mathrm{m} \mathrm{min}^{-1}\right)\end{array}$ & $\begin{array}{l}\text { Supply speed (SS) } \\
\left(\mathrm{m} \mathrm{min} \min ^{-1}\right)\end{array}$ & $\begin{array}{l}\text { Rotational speed } \\
(\mathrm{RS})\left(\mathrm{min}^{-1}\right)\end{array}$ & $\begin{array}{l}\text { Theoretical number of wraps } \\
\left(W_{\text {theoretical }}\right)\left(\mathrm{m}^{-1}\right)\end{array}$ & $\begin{array}{l}\text { Overfeed ratio } \\
(\eta)(\%)\end{array}$ & $\begin{array}{l}\text { Resultant } \\
\text { bouclé yarn }\end{array}$ \\
\hline 1 & 30 & 54 & 6000 & 200 & 180 & Yarn I(1) \\
\hline 2 & 30 & 60 & 6000 & 200 & 200 & Yarn I(2) \\
\hline 3 & 30 & 66 & 6000 & 200 & 220 & Yarn I(3) \\
\hline 4 & 30 & 72 & 6000 & 200 & 240 & Yarn I(4) \\
\hline 5 & 30 & 78 & 6000 & 200 & 260 & Yarn I(5) \\
\hline
\end{tabular}

Table 3 Machine settings and yarn structure when testing the effect of the number of wraps

\begin{tabular}{|c|c|c|c|c|c|c|}
\hline $\begin{array}{l}\text { Machine } \\
\text { setting }\end{array}$ & $\begin{array}{l}\text { Delivery speed (DS) } \\
\left(\mathrm{m} \min ^{-1}\right)\end{array}$ & $\begin{array}{l}\text { Supply speed (SS) } \\
\left(\mathrm{m} \mathrm{min} \min ^{-1}\right)\end{array}$ & $\begin{array}{l}\text { Rotational speed } \\
\text { (RS) }\left(\mathrm{m}^{-1}\right)\end{array}$ & $\begin{array}{l}\text { Theoretical number of wraps } \\
\left(W_{\text {theoretical }}\right)\left(\mathrm{m}^{-1}\right)\end{array}$ & $\begin{array}{l}\text { Overfeed ratio } \\
(\eta)(\%)\end{array}$ & $\begin{array}{l}\text { Resultant } \\
\text { bouclé yarn }\end{array}$ \\
\hline 1 & 30 & 60 & 4800 & 160 & 200 & Yarn II(1) \\
\hline 2 & 30 & 60 & 5100 & 170 & 200 & Yarn II(2) \\
\hline 3 & 30 & 60 & 5400 & 180 & 200 & Yarn II(3) \\
\hline 4 & 30 & 60 & 5700 & 190 & 200 & Yarn II(4) \\
\hline 5 & 30 & 60 & 6000 & 200 & 200 & Yarn II(5) \\
\hline 6 & 30 & 60 & 6300 & 210 & 200 & Yarn II(6) \\
\hline 7 & 30 & 60 & 6600 & 220 & 200 & Yarn II(7) \\
\hline
\end{tabular}

used for counting the size or the circularity ratio of bouclé profile. A digital image analysis software package called "analySIS FIVE®" was used to analyze the digital photographs by drawing an ultimate, fitted polygon around the projection of fancy profile when viewed from the top. The same digital image analysis software was used to measure the area of bouclé profile and the circularity ratio of bouclé profile. Sampling was carried out according to procedures approved by ISO standards (EN ISO 6939:1988). The systematic method of sampling was used to select a representative sample for the fancy profiles. The three meters of fancy yarn at the beginning of each package were discarded in order to avoid damaged sections or sections made at the start-up of the machine. The specimens were wound off the package slowly, smoothly and with care to prevent un-wrapping of the binder wraps or making the fancy yarns snarl on themselves.

When counting the number of bouclé profiles, the specimens were fixed by an adhesive tape on a metal ruler without cutting the bouclé yarns or separating them from the packages. Doing this ensured that the yarns were always straight without affecting the number of wraps. To select one decimeter-long yarn segments along the fancy yarns, a manual winding reel was used to separate the $10 \mathrm{~cm}$ samples by a distance equaling the sampling pitch. To account for the size of boucle profile, the first fancy bouclé profile was selected randomly from each bouclé yarn, while the other profiles selected were spaced apart along each fancy yarn by a distance equaling the sampling pitch. Accounting for the circularity ratio of bouclé profile, followed the same approach that was used for the size of bouclé profile. The linear density was measured depending on the procedures mentioned in the international standard EN ISO 2060:1995. The bouclé yarns were first preconditioned and then conditioned according to standard EN ISO 139:2005. The weight of the specimens was measured using a digital scale with $0.0001 \mathrm{~g}$ sensitivity. The details of the sampling regime and specimens for each of these properties are given in Table 4. All calculations and statistical studies were accomplished using Minitab 17.

\section{Results and Discussion}

\section{Results of Impact of Overfeed Ratio on the Structure of Bouclé Yarns}

The bouclé yarns made to assess the impact of overfeed ratio on the structure of bouclé yarns are shown in Fig. 1, and they were five yarns in total. This figure shows that these yarns had dominating bouclé profiles, some semibouclé profiles (semi-bouclé profiles), a few fancy undulations and sigmoidal sections and a minority of loops. This figure also shows that the number and size of bouclé 
Table 4 Sample details for the tests

\begin{tabular}{llll}
\hline Fancy yarn structure characteristic & Specimen size & Number of specimens & Sampling distance or pitch \\
\hline Number of bouclé profile & $10 \mathrm{dm}$ & 16 & $2 \mathrm{~m}$ \\
Size of bouclé profile & Not applicable & 15 & $50 \mathrm{~cm}$ \\
The circularity ratio of bouclé profile $(\%)$ & Not applicable & 15 & $50 \mathrm{~cm}$ \\
Linear density of the yarn & $10 \mathrm{~m}$ & 3 & $2 \mathrm{~m}$ \\
Actual number of the binder wraps & $1 \mathrm{~m}$ & 3 & $10 \mathrm{~m}$ \\
\hline
\end{tabular}

Fig. 1 Images of the fancy yarns made to test the influence of the overfeed ratio of the effect thread on the structure of bouclé yarn

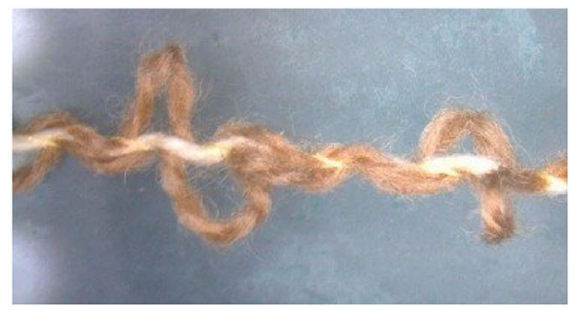

Yarn I(1)

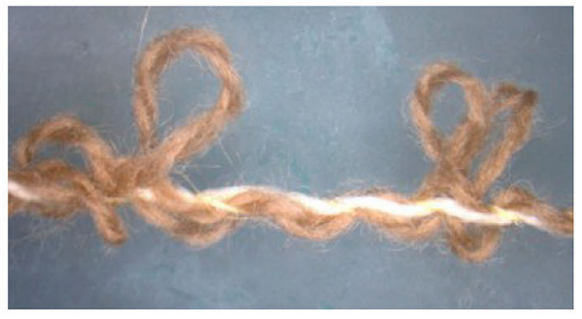

Yarn I(3)

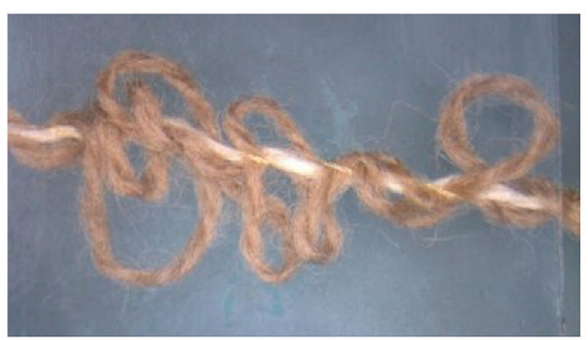

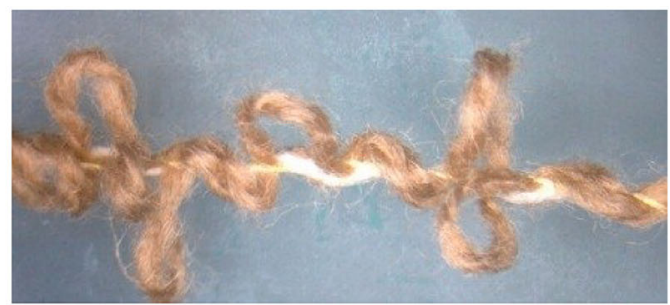

Yarn I(2)

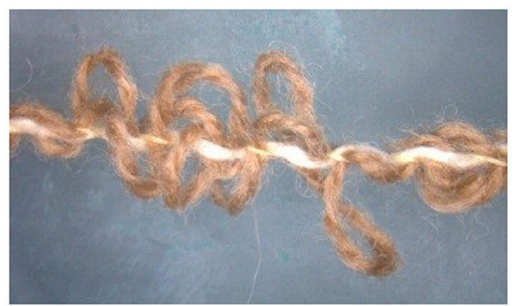

Yarn I(4)

Yarn I(5)

profiles increased from yarn I(1) until yarn I(5). However, the bouclé and semi-bouclé profiles started to cluster in yarns I(4) and I(5), which reduced their aesthetics and thus their appeal to customers in comparison with yarns I(1) to I(3). These yarns were tested objectively as explained above, and the numerical results are given in Table 5 . Table 5 indicates that the higher the overfeed ratio, the larger the boucle profiles and the higher the levels of variability of the size of these profiles. It was found that these relationships were linear and the regression equations were:
$A=-34.0+0.259 \times \eta$

$\mathrm{SD}_{A}=-6.254+0.6511 \times A$

where the mean value and standard deviation (SD) of the size of boucle profile are measured in $\mathrm{mm}^{2}$ and $\eta(\%)$ is the (theoretical) overfeed ratio up to a value of $240 \%$.

Equation (4) can be useful to predict the level of variation associated with the mean value of the size of boucle profile. The increase in the size of boucle profile when increasing the overfeed ratio was explained by considering the first spinning zone on the hollow-spindle spinning machine. It was reported that the geometry of the effect- 
Table 5 The results of testing the influence of the overfeed ratio of the effect thread

\begin{tabular}{|c|c|c|c|c|c|c|c|c|}
\hline \multirow[t]{2}{*}{ Bouclé yarn } & \multirow[t]{2}{*}{$\begin{array}{l}\text { Overfeed } \\
\text { ratio, } \eta(\%)\end{array}$} & \multicolumn{2}{|c|}{$\begin{array}{l}\text { Size of bouclé profile } \\
\left(\mathrm{mm}^{2}\right)\end{array}$} & \multicolumn{2}{|c|}{$\begin{array}{l}\text { Circularity ratio of fancy bouclé } \\
\text { profile }(\%)\end{array}$} & \multicolumn{2}{|c|}{$\begin{array}{l}\text { Number of fancy bouclé profiles } \\
\left(\mathrm{dm}^{-1}\right)\end{array}$} & \multirow{2}{*}{$\begin{array}{l}\text { Shape factor } \\
\text { of fancy bouclé } \\
\text { yarn }\left(\mathrm{mm}^{2} \mathrm{dm}^{-1}\right)\end{array}$} \\
\hline & & Average & SD & Average & SD & Average & SD & \\
\hline Yarn I(1) & 180 & 13.57 & 3.17 & 60 & 17 & 11.93 & 2.25 & 161.94 \\
\hline Yarn I(2) & 200 & 16.28 & 4.03 & 55 & 14 & 13.40 & 1.88 & 218.11 \\
\hline Yarn I(3) & 220 & 22.18 & 8.15 & 53 & 17 & 15.73 & 3.13 & 348.82 \\
\hline Yarn I(4) & 240 & 29.85 & 11.17 & 50 & 18 & 15.93 & 1.83 & 475.52 \\
\hline Yarn I(5) & 260 & 32.66 & 16.79 & 56 & 16 & 16.40 & 2.77 & 535.61 \\
\hline
\end{tabular}

thread helices in this zone had a direct relationship with the structure of the resultant multi-thread fancy yarn $[9,10]$. Further, it was reported that increasing the overfeed ratio led to an increase in the diameter of the effect-thread helices formed in this zone. This in turn resulted in large fancy profiles, including bouclé profiles [9, 10]. Further, the variation in the size of bouclé profile were attributed to several reasons as follows. Firstly, the variability of geometry of the effect-thread helices in the first spinning zone may result in variation in the size and number of the fancy profiles. Secondly, the high levels of the supply speed needed to produce high overfeed ratios may have resulted in high levels of vibration in the machine parts. Due to the lighter weight and size of the threads, the vibration transmitted from the machine parts to the threads in the first spinning zone is normally greater in magnitude than that of the machine parts. Consequently, it may have caused unstable movement of the threads and their helices, thus unstable spinning geometry. These in turn can severely affect the formation of fancy profiles during the formation of the intermediate product within the hollow spindle. However, a stiff effect thread is less likely to conform to the machine vibration than a softer effect thread. Therefore, using a relatively stiff effect thread may suffice to reduce the variability in the size of the profiles when raising production speeds. Thirdly, when the overfeed was increased, the irregular transformation of existing fancy profiles, other than bouclé profile, into new bouclé profiles may have resulted in variation in the size and number of the new population of bouclé profiles, as previously reported analytically [17]. This is because an increase in the overfeed ratio may increase the height of all types of fancy profile on the fancy yarn. Consequently, it may create new bouclé profiles and increase the size of the bouclé profiles already available on the fancy yarn.

It is shown in Table 5 that as the overfeed ratio increased by increasing the overfeed ratio of the effect component, so did the number of bouclé and semi-bouclé profiles $(\mathrm{N})$. It was also found that this relationship was a simple, linear regression model as given by Eq. (5). The variability of this bouclé yarn property, as given in Table 5, did not have any clear trend with the overfeed ratio.

$N=2.06+0.0574 \times \eta$

These results were obtained because, as demonstrated analytically previously, increasing the overfeed ratio can create new bouclé profiles and semi-bouclé profiles [17]. This is because high overfeed ratio can provide sufficient lengths of the effect threads to some of the arcs, waves and sigmoidal sections of the boucle yarn to grow larger. Therefore, the heights of those sections may have increased to be approximately similar to the heights of the bouclé profiles already available on the fancy yarn. As a result, new bouclé profiles formed at the expense of a reduction in the number of the arcs, waves and sigmoidal sections. However, such an increase in the height of those profiles was not regular. Additionally, there was also an increase in the height of the boucle profiles already available on the fancy yarn. Subsequently, the sizes of the old and the new bouclé profiles were not equal and not consistent. As a result, the variation in the size of the profile also increased with increasing the overfeed ratio.

Eventually, the increase in both the number and size of bouclé profiles will lead to an increase in the value of their product, which is the shape factor of boucle yarn (ShF). Although the manner of such an increase was not shown before [17], the findings of this study confirmed that the shape factor of bouclé yarn increased with the overfeed ratio linearly according to Eq. (6). Based on that, low values of overfeed ratio made bouclé yarns with a relatively low amount of absolute fancy bulkiness (Table 5).

$\mathrm{ShF}=-757+5.02 \times \eta$

In regard to the circularity ratio of boucle profile, the results of Table 5 shows that increasing the overfeed ratio reduced their circularity ratio up to an overfeed ratio equaling $240 \%$. However, the surge in the circularity ratio (CR) when the overfeed ratio $(\eta)$ was $260 \%$ was ignored in the analysis because the boucle profiles had no stable shape and were prone to deformation easily, even while being 
Fig. 2 Images of the bouclé yarns made to test the effect of the number of wraps on the structure of bouclé yarn

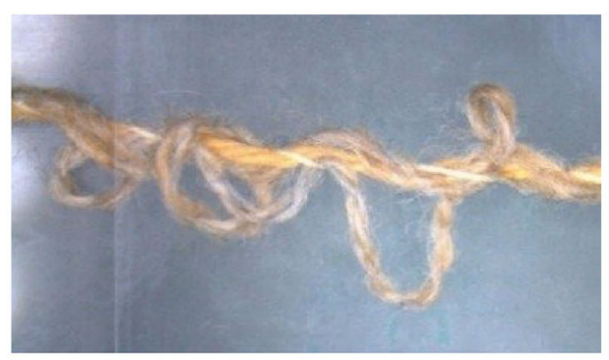

Yarn II(1)

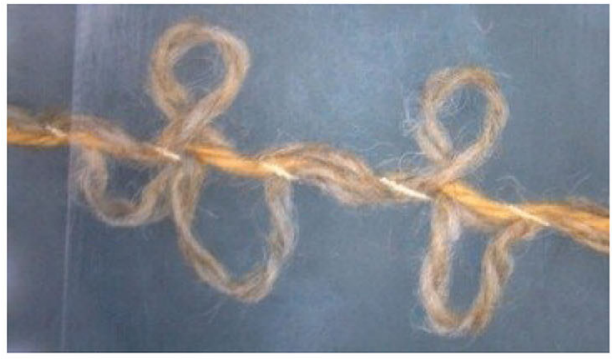

Yarn II(3)

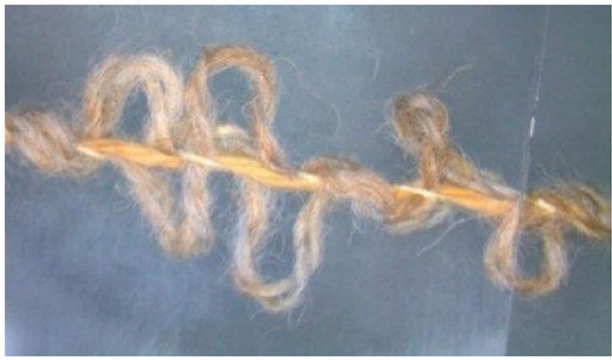

Yarn II(5)

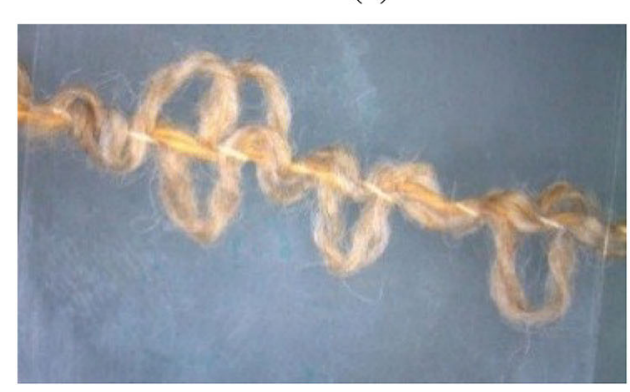

Yarn II(7)

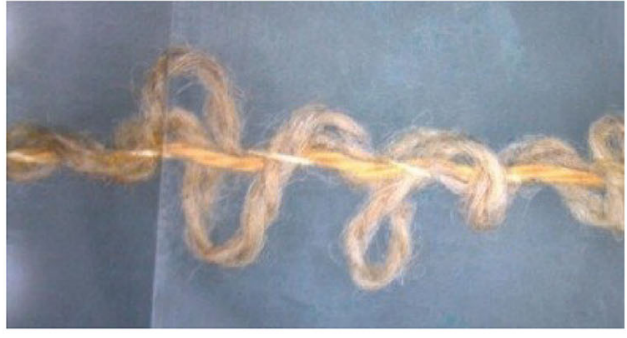

Yarn II(2)

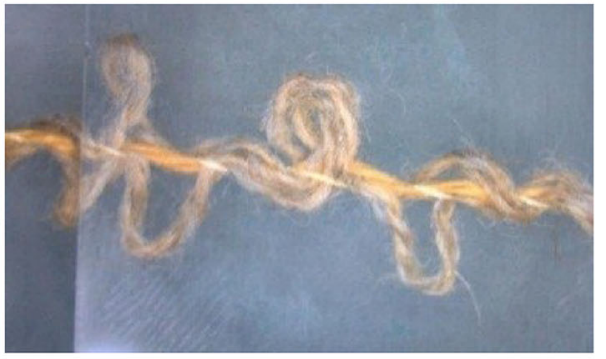

Yarn II(4)

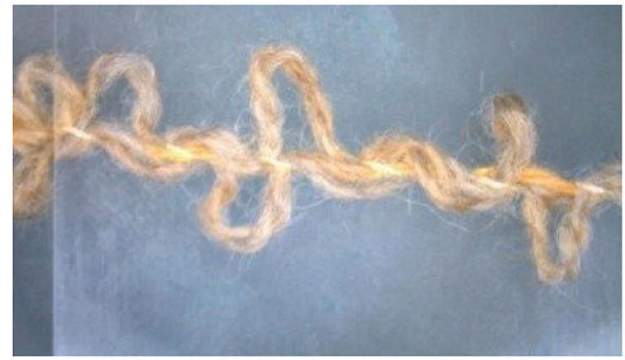

Yarn II(6)
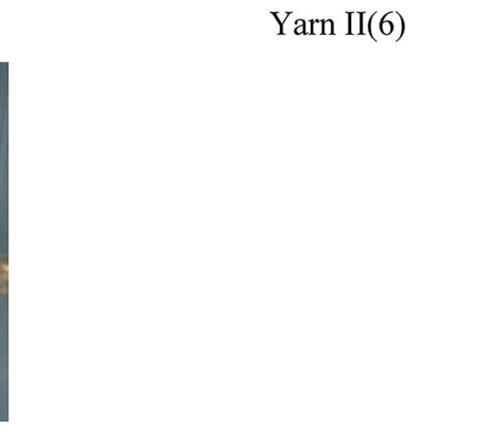
Table 6 The results of testing the effect of the number of wraps

\begin{tabular}{|c|c|c|c|c|c|c|c|c|}
\hline \multirow[t]{2}{*}{ Bouclé yarn } & \multirow[t]{2}{*}{$\begin{array}{l}\text { Theoretical number } \\
\text { of wraps }\left(\mathrm{m}^{-1}\right)\end{array}$} & \multicolumn{2}{|c|}{$\begin{array}{l}\text { Measured number of } \\
\text { wraps }\left(\mathrm{m}^{-1}\right)\end{array}$} & \multicolumn{2}{|c|}{$\begin{array}{l}\text { Size of fancy bouclé } \\
\text { profile }\left(\mathrm{mm}^{2}\right)\end{array}$} & \multicolumn{2}{|c|}{$\begin{array}{l}\text { Number of fancy bouclé } \\
\text { profiles }\left(\mathrm{dm}^{-1}\right)\end{array}$} & \multirow[t]{2}{*}{$\begin{array}{l}\text { Shape factor of fancy } \\
\text { bouclé yarn }\left(\mathrm{mm}^{2} \mathrm{dm}^{-1}\right)\end{array}$} \\
\hline & & Average & SD & Average & SD & Average & SD & \\
\hline Yarn II(1) & 160 & 184 & 6.5 & 21.64 & 7.62 & 13.40 & 1.68 & 289.99 \\
\hline Yarn II(2) & 170 & 192 & 8.4 & 17.76 & 7.91 & 13.93 & 2.08 & 247.33 \\
\hline Yarn II(3) & 180 & 198 & 16.8 & 18.63 & 5.28 & 14.07 & 1.48 & 262.08 \\
\hline Yarn II(4) & 190 & 204 & 5.5 & 16.96 & 4.17 & 14.07 & 2.53 & 238.60 \\
\hline Yarn II(5) & 200 & 216 & 16.4 & 16.31 & 4.26 & 13.80 & 2.04 & 225.04 \\
\hline Yarn II(6) & 210 & 223 & 15.7 & 15.15 & 4.41 & 14.80 & 2.48 & 224.20 \\
\hline Yarn II(7) & 220 & 233 & 4.5 & 14.09 & 2.90 & 13.38 & 2.02 & 188.47 \\
\hline
\end{tabular}

Table 7 Significance test results of regression equations

\begin{tabular}{lll}
\hline Equation & $P$-value of ANOVA & Significance at $\alpha=0.05$ \\
\hline Equation (3) & 0.002 & Yes \\
Equation (4) & 0.007 & Yes \\
Equation (5) & 0.017 & Yes \\
Equation (6) & 0.001 & Yes \\
Equation (7) & 0.017 & yes \\
Equation (8) & 0.002 & Yes \\
Equation (9) & 0.002 & Yes \\
Equation (10) & 0.000 & Yes \\
\hline
\end{tabular}

further increases in the overfeed ratio may force the bouclé profiles to assume a new elongated shape, thus reducing their circularity ratio.

\section{Results of Impact of the Number of Wraps on the Structure of Bouclé Yarns}

The bouclé yarns made for testing the effect of number of wraps on bouclé yarn structure are shown in Fig. 2 which indicates that these yarns had bouclé profiles, wavy sections, sigmoidal sections and semi-bouclé profiles (bouclélike profiles). It is shown that the yarn structure became tighter and more compact and the bouclé profiles became smaller starting from yarn II(1) until yarn II(7). However, the number of bouclé profiles increased when observing the boucle yarns in the same order. These changes to the nature of the structure of these yarns mean that they have various aesthetic and appeal levels that allow them to match the various needs of different customers. The numerical results of the testing procedures are given in Table 6. This table indicates that increasing the number of wraps reduced the size of the bouclé profiles $(A)$. This relationship represented a linear regression model as given in Eq. (8):

$A=37.7-0.108 \times W_{\text {theoretical }}$

Changing the number of wraps affected the size of bouclé profile because when the number of wrap increases, the distance between successive wraps of the binder decreases proportionally. Therefore, the width of bases of the profiles becomes narrow, while their circumferences become short. Consequently, the area of the profiles becomes small. Since the area of boucle profile defines its size, the size of bouclé profile becomes small. Further, the arcs, waves and sigmoidal sections of the boucle yarn receive the lengths of the effect threads that were supposed to make larger bouclé profiles. Eventually, those arcs, waves and sigmoidal sections become bulky and have wider diameters than their original size.

Table 6 also shows that high numbers of wraps result in low variation in the size of the profiles, while low numbers of wraps allowed for more variation in the size of the profiles. Consequently, high numbers of wraps reduced the average size of bouclé profiles and improved their consistency. This is because the extra wraps added to the boucle yarn reduce the distance available for the legs of the boucle profiles to project out of the bouclé yarn surface. Consequently, reductions in the variability of the size of the profiles happen by raising the number of wraps. The 
decrease in the size of boucle profile, even though the overfeed ratio $(\eta)$ was kept unchanged, meant that the sigmoidal sections of the bouclé yarns became bulkier with wider diameters then their original size. This type of change in appearance and texture of multi-thread fancy yarn is normally reflected through different values of the shape factor of bouclé yarn as shown below.

The results in Table 6, however, did not indicate any obvious or remarkable change in the number of bouclé profiles when the number of wraps was changed. Additionally, no obvious change has happened to the variability of number of bouclé profiles; therefore, this variation was thought to be a random variation. However, Table 6 shows that when the number of wraps was increased, the shape factor of fancy yarn (ShF) decreased. This reduction was related to the reduction in the size of bouclé profiles. The ShF was $290 \mathrm{~mm}^{2} \mathrm{dm}^{-1}$ for $W=160 \mathrm{~m}^{-1}$, but it was as low as $190 \mathrm{~mm}^{2} \mathrm{dm}^{-1}$ for $W=220 \mathrm{~m}^{-1}$. In effect, a 100 $\mathrm{mm}^{2} \mathrm{dm}^{-1}$ reduction in the absolute fancy bulkiness of bouclé profiles was a large change in the quality of the bouclé yarns for a $60 \mathrm{~m}^{-1}$ change in the number of wraps. The linear regression model represented by Eq. (9):

$\mathrm{ShF}=503-1.39 \times W_{\text {theoretical }}$

It is found that there were differences between the number of wraps set using the machine (i.e. the theoretical number of wraps, $W_{\text {theoretical }}$ ), and the real number of wraps (which was received by the bouclé yarns and measured subsequently, $W_{\text {measured }}$ ) as shown in Table 6. However, there was a linear relationship given in Eq. (10) as follows:

$W_{\text {measured }}=53.11+0.8107 \times W_{\text {theoretical }}$

\section{Statistical Analysis}

The regression equations of this study were found to be significant at a significance level $\alpha=0.05$ as shown in Table 7. This means each of these equation can be used to predict the property it accounts for.

\section{Conclusions}

It is concluded that when increasing the overfeed ratio of the effect component from 180 to $240 \%$ has increased the size of bouclé and semi-bouclé profiles from $\sim 13$ to $\sim 29 \mathrm{~mm}^{2}$, increased the number of bouclé and semibouclé profiles from $\sim 12$ to 16 profile per $\mathrm{dm}$ and increased the fancy bulkiness or fullness of the boucle yarns from $\sim 162$ to $\sim 475 \mathrm{~mm}^{2} \mathrm{dm}^{-1}$. This means that the morphology of bouclé profiles changed considerably by changing the overfeed ratio, but the profiles remained bouclé or semi-bouclé profiles. It was also found that the variability of size of bouclé and semi-bouclé profiles was proportional to the mean value of the size of boucle profile. In all these results, the relationships were linear and significant at a significance level $\alpha=0.05$.

It is also concluded that when increasing the number of wraps of the binder from 160 to $220 \mathrm{~m}^{-1}$, the size of the bouclé profiles decreased significantly from $\sim 21.6$ to 14 $\mathrm{mm}^{2}$, but consistency of the size of profiles has improved because the standard deviation decreased from $\sim 7.5$ to 3 $\mathrm{mm}^{2}$. These changes resulted in a significant reduction of the fancy bulkiness of the bouclé yarns from $\sim 290$ to 188 $\mathrm{mm}^{2} \mathrm{dm}^{-1}$. However, both the circularity ratio of bouclé profile and the number of bouclé and semi-bouclé profiles were not affected by the changes to the number of wraps.

\section{Funding None.}

\section{Declarations}

Conflict of interest The authors declare that they have no conflict of interest.

Open Access This article is licensed under a Creative Commons Attribution 4.0 International License, which permits use, sharing, adaptation, distribution and reproduction in any medium or format, as long as you give appropriate credit to the original author(s) and the source, provide a link to the Creative Commons licence, and indicate if changes were made. The images or other third party material in this article are included in the article's Creative Commons licence, unless indicated otherwise in a credit line to the material. If material is not included in the article's Creative Commons licence and your intended use is not permitted by statutory regulation or exceeds the permitted use, you will need to obtain permission directly from the copyright holder. To view a copy of this licence, visit http://creativecommons.org/licenses/by/4.0/.

\section{References}

1. M.J. Denton, P.N. Daniels, Textile Terms and Definitions, 11th edn. (The Textile Institute, Manchester, 2002)

2. B.U. Nergis, C. Candan, Performance of bouclé yarns in various knitted fabric structures. Text. Res. J. 76(49), 49-56 (2006)

3. A. Ragaišienè, S. Petrulyte, Design of fancy yarns with worsted and elastomeric covered components. Mater. Sci. (Medžg.) 9(4), 414-418 (2003)

4. A. Ragaisiene, Influence of overfeed and twist on fancy yarns structure. Mater. Sci. (Medžg.) 15(2), 178-182 (2009)

5. S. Petrulyte, Analysis of structural effects formation in fancy yarn. Indian J. Fibre Text. Res. 32, 21-26 (2007)

6. S. Petrulyte, Influence of technological parameters on the periodical effects of fancy yarns. Fibres Text. East. Eur. 16(3), 25-29 (2008)

7. A. Ragaisiene, Interrelation between the geometrical and structural indices of fancy yarns and their overfeed and twist. Fibres Text. East. Eur. 17(4), 26-30 (2009)

8. S. Petrulytè, D. Petrulis, Influence of twisting on linen fancy yarn structure. J. Nat. Fibers 11(1), 74-86 (2014). https://doi.org/10.1080/15440478.2013.842512

9. M. Alshukur, D. Yurchenko, Experimental study on the spinning geometry of multi-thread fancy yarn on hollow-spindle spinning 
machines: part I. Int. J. Cloth. Sci. Technol. 30(4), 496-506 (2018). https://doi.org/10.1108/IJCST-05-2017-0064

10. M. Alshukur, D. Yurchenko, Experimental study on the spinning geometry of multi-thread fancy yarn on hollow-spindle spinning machines: part II. Int. J. Cloth. Sci. Technol. 31(4), 454-461 (2019). https://doi.org/10.1108/IJCST-05-2017-0065

11. K.E. Grabowska, Mathematical modeling of tensile properties of fancy loop yarns. Theoretical: Part I. Text. Res. J. 80(18), 1905-1916 (2010)

12. M. Alshukur, A. Fotheringham, Quality and structural properties of gimp fancy yarns using the design of experiments. J. Text. Inst. 106(5), 490-502 (2015). https://doi.org/10.1080/00405000. 2014.927126

13. B.U. Nergis, C. Candan, Performance of rib structures from boucle yarns. Fibres Text. East. Eur. 15(2), 50-53 (2007)

14. M. Alshukur, A. Fotheringham, H. Gong, Relationship between the interaction of bending stiffness of component yarns and the structure of fancy bouclé and semi-bouclé yarns. Fibers Polym. 21(2), 437-446 (2019). https://doi.org/10.1007/s12221020-8156-0

15. M. Alshukur, A. Fotheringham, H. Gong, Influence of component stiffness on the structure of multi-thread, fancy bouclé yarn. J. Ind. Text. 49(7), 889-905 (2020). https://doi.org/10.1177/ 1528083718801365
16. M. Alshukur, D. Sun, Effect of core thread tension on structure and quality of multi-thread bouclé yarn. Indian J. Fibre Text. Res. 41(4), 367-372 (2016)

17. M. Alshukur, H. Gong, G. Stylios, Structural modelling of multithread fancy yarn. Int. J. Cloth. Sci. Technol. 30(2), 268-283 (2018). https://doi.org/10.1108/IJCST-05-2017-0063

18. M. Alshukur, L. Macintyre, Bending rigidity of yarns using beam method on a two-support configuration. Indian J. Fibre Text. Res. 45(1), 40-48 (2020)

19. M. Alshukur, The quality of fancy yarn: Part I: Methods and concepts. Int. J. Text. Fash. Technol. 3(1), 11-24 (2013)

20. M. Alshukur, The quality of fancy yarn: Part II: Practical experiments and application. Int. J. Text. Fash. Technol. 3(1), 25-38 (2013)

21. M. Alshukur, A. Fotheringham, Structural ratio of multi-thread fancy yarn: interaction effect of both the number of wraps and the overfeed ratio on fancy bouclé yarn structure. J. Nat. Fibers (2019). https://doi.org/10.1080/15440478.2019.1692320

Publisher's Note Springer Nature remains neutral with regard to jurisdictional claims in published maps and institutional affiliations. 